\title{
An Empirical Evaluation on Performance of Organization through Human Resource Accounting (HRA): A Study on Selected Corporate Units of India
}

\author{
Atul Bansal $P h D$ \\ Associate Professor (Accounting and Finance) \\ Department of Commerce, J.V.Jain College, Saharanpur (UP), India \\ Email id: dr.atulbansal@gmail.com \\ Mobile : +91 8899470388 \\ Preeti Sharma $P h D$ \\ Professor \& Head \\ School of Business Management \\ University of Engineering \& Management, Jaipur,India \\ E-mail id:sh_preeti@rediffmail.com \\ Mobile No : 7891233350
}

\begin{abstract}
This study attempts to analyze the importance of Human Resource Accounting (HRA) practices for corporate financial reporting. This paper is both a theoretical and empirical exploration, aimed to some suggestions of new thoughts, methods, techniques and applications of HRA. Various MNCs in the field of HRM provide different types of thought about the practices of personnel management with different systems and aims of financial analysis and reporting. HRM has been and remains one of the most powerful and influential ideas to have emerged in the field of business and management. Effective practices of human resources in the accounting statement can ensure long-term benefits to the employees of the corporations and it also increases quality, performance, values, and commitment to future need. The data of this study was collected from secondary and primary sources from selected corporate units. Very few corporations are practically practices this concept in their accounting and financial report. Some findings and suggestions are addressed in the study that may be the prerequisite for organizational growth and development.
\end{abstract}

Keywords:Human Resource Accounting (HRA), Indian Human Resource Practices,Lev and Schwartz model Effectiveness, Human Assets, Financial Reporting

\section{Introduction and / or Statement of the Problem}

Human Resource Accounting (HRA) is the process of identifying, measuring data about human resources and communicating this information to interested parties. The major benefits of such accounting are that it develops effective managerial decision making, quality of management, prevents misuse of human resources, increases human asset productivity, improve morale, job satisfaction, performance appraisal, motivation and creativity, etc. To ensure growth and development of any organization, the efficiency of people must be augmented in the right perspective. Without human resources, the other resources cannot be operationally effective. The original health of the organization is indicated by the human behavior variables, like group loyalty, skill, motivation, quality and capacity for effective interaction, cooperation, communication and decision making. Men, materials, machines, money and methods are the resources required for an organization. These resources are broadly classified into two types such as human and physical resources. Men, otherwise known as the human resources, are considered to be animate resources. Others, namely, materials, machines, money and methods are considered to be inanimate or physical resources. Human Resource Accounting (HRA) is a new concept of accounting. It follows the traditional theory that all expenditure on human capital formation is taken as a charge against the revenue of the period as it does not create any physical asset. But modern view is that cost incurred on any asset as human resources need to be capitalized as it provides benefits measureable in monetary terms. Measurement of cost and value of the people to organizations is highly important, costs incurred in recruitment, selection; hiring, training and development of employees along with their economic values are very much relevant for Human Resource Accounting. All the processes of the organization are operated by human resource, so valuation of this resource is very necessary and 
information about the valuation should be given to the investors, the management and others through financial statements. Human resource accounting is basically an information system that explains management what changes are occurring over time to the human resources of the business. In the early 1990s industries were recognized the value and importance of human assets. Skillful and specialized human resources are of vital importance for an organization just like its physical properties and investments. Managers of the organizations spend a lot of money for training and educating their workers and employees in order to increase the efficiency of the organization under their control, but human resources accounting system which should be used for human resources information processing have not been used practically by any organization. In this study, an alternative to the traditional methods of accounting for human worth has been proposed. The concept of Human Resource Accounting was developed to give management an accurate estimation of the value of people to the organization. The HRA is being developed to provide a system that the goals are to define present human resource value and to predict future human resource value to the organization. The Human Resource Accounting is an application of the technology of a basic management dimension return on investment (ROI) from human resources as program justification, evaluation of promotion policies, prediction of human asset costs associated with new construction overruns, estimation of personnel costs associated with adjusting of an organization and evaluation of detailing and assignment procedures.

\section{Rationale and Scope of the Study}

Management of human resources in any organizations is very much important from accounting point of view. Valuation of human resources, recording the valuation in accounts and fair disclosure of such information in financial statements are the demand of the stakeholders to enhance managerial performance and employees' productivity. Investment in developing human resources is not revenue expenditure. Its impact on developing the capability of employees provides benefits for a long period. There is a genuine need for reliable and complete information that can be used in improving and evaluating human resource management. HRA is actually a part of social accounting in which accountants need to apply their specialized abilities to help find solutions to our social problems. We know that accounting is a science of measurement, analysis and communication. The designing of proper accounting system for providing information to the stakeholders is also a difficult task. The information concerning human assets is more relevant to a great variety of decisions made by external and internal users. Accounting for human asset constitutes an explicit recognition of the premise that people are valuable organizational resources and an integral part of a mix of resources. This study will be helpful for the different users of accounting information for their day to day decision making. This study, therefore, will help to presents a critical assessment of the concept of HRA thereby unveiling its strengths and weaknesses. The study also presents the likely impact that reporting human resource as assets will have on the quality and quantity of companies' corporate financial reports. The basic premises underlying the practices of human resource accounting are:

- People are valuable physical resources of an organization.

- The usefulness of HR as an organizational resource is determined by the management and

- Information on investment and value of human resource is useful for decision making in the organization.

\section{Need \& Problems of HRA}

It is fact that the 21st century is era of Human demand, countries those have labor quality ruling the world with dominant technology. Countries like china and Japan forerunners in technology advancement, is all result of work force performance. Hence whole world realized that human resource is the real investment into business ventures that should only catch and stick the success waves. Human Resource accounting can be defined as an application of financial skills, and an investigative mentality to unresolved issues, conducted within the context of rules of evidence. As a discipline, it encompasses financial expertise, fraud knowledge and a sound knowledge and understanding of business reality and the working of the legal system." This implies that the Human Resource accountant should be skilled not only in financial accounting, but also in internal control systems, the law, other institutional requirements, investigative proficiency, and interpersonal skills. Corporations can rely on these skills for developing a consistent system of corporate governance, disseminating such information within and outside the company, ensuring that governance policies and objectives are interwoven into the internal control system, setting up fraud prevention systems, and investigating any existing fraud. Human Resource is a term which refers to the set of individuals who make up the workforce of an organization or a business entity. The work of Bassey \&Tapang (2012) points to the fact that human resources .have been identified as one of the main sources of competitive advantage by many organizations in today's economy. Particularly, the private sector organization is widely diverse and has focused on human resources as having special strategic value for organization development. Abdullahi \& Kirfi (2012) maintain that the quantification of the value of Human Resources helps the management to cope up with the changes in its quantum and quality so that equilibrium can be achieved in-between the required resources and the provided human resources. As a result, it becomes imperative to put measures in place to effectively manage people with their needs and expectations to enhance Productivity. Therefore, proper appreciation of human resource 
accounting will enable managers take appropriate decisions regarding investment in human resources. It will also provide comparative information regarding costs and benefits associated with investments in human assets. HR Accounting is very much needed to provide effective \& efficient management within the organization.

\section{Aims and/or Objectives of the Study}

This study is an attempt for achievement of two major objectives of the human resource accounting practices in national corporations.

4.1 General Objective: To analyze the importance of HRA in HRM decision from an organizational perspective by increasing the transparency of human resource costs, investments and outcomes in profit and loss accounts, balance sheets and investment calculations.

4.2 Specific Objectives: The specific objectives are:

- To analyze and evaluate the HRA plans and policies from previous literature review and applications of HRA in different organizations.

- To evaluate the execution of HRA programs in financial statements and to identify the strength and weakness of HRA practices in the organizations.

- To provide information to all people concerned regarding the efficiency of HR in obtaining productivity and profitability.

- To facilitate valuation of human resources, recording the valuation in the books of account and disclosure of the information in the financial statement.

- To provide some arguments and suggestions with a view to increasing the use of HRA in most of the corporations in India.

\section{Conceptual Framework}

Given the problem and the theoretical perspective for investigation of the problem, the proposal should clearly bring out the concepts to be used and demonstrate their relevance for the study. Besides, the dimension of empirical reality that needs to be explored for investigating the problem should also be specified.

\subsection{Historical Cost Method}

This method was developed by Brummet Fand W.C. Pyle. Under this method capital expenditure on human assets are amortized over an expected life of human assets. When employee is leaving early than unrecovered will be treated loss and charge to P\&L A/c. However it is difficult to find out the effective life of human assets and fix the rate at which cost be amortized.

\subsection{Replacement Cost Method}

This method was developed by R.Likert and E.G. Flamhottz. Under this method all the cost of replacement are considered when an employee is replaced (i.e, recruiting, training, placing etc.) with a person of equal ability. This method of suggests a current value of the human assets. It is difficult to determine the replacement cost of an employee and replacement cost does not reflect the competence of an employee.

\subsection{Opportunity Cost Method}

This method was developed by Hekimian and Jones. Under his method opportunity cost's are considered as an asset value when the target of an alternative use. Only scarce human resources would have value at any particular point of time. Opportunity cost is calculated on the basis of efforts made by several organizational units, profit centers or departments.

\subsection{Competitive Bid Price Method}

It is developed by Hekimian and Jones. Under this method human resources are valued on the bidding cost. Only scarce work force or employees are considered under this method. The value of human assets is determined by capitalizing the total of bid prices of all the scarce employees within the company

5.5 Standard Cost Method

This method was developed by David Watson. Under this method standard cost of recruitment training and professional Growth for each grade or category of Employees are fixed and compared with actual after recruitment and replacement. Variance if any is charged to profit \& loss account.

5.6 Current Purchasing Power Method

In this approach investment in human assets or workforce is converted into the current purchasing power of money with help of index number. It is difficult to find suitable index in the changing scenario therefore; this method may not be representative of actual value of human resources.

\subsection{Human Resource Accounting Practicing Companies in India}

Even though, many benefits have contributed by HRA, yet its development and application in different industries has not been encouraging. Because Indian companies act 1956, does not provide any scope for showing any information about human resources in financial statement. Due to the development of business and industries, some 
of the Indian companies, both public and private, value their human resources and report this information in their annual report. The companies, who are presently reporting human assets valuation, include:

- Oil and Natural Gas Commissioning (ONGC).

- Hindustan Petrolium Corporation Limited (HPCL)

- Oil India Ltd

- Cement corporation of India. (CCI).

\section{Human Resource Accounting in India}

There certain major issues relating to implementation of human resources accounting arises because of it try to attempt measure and evaluate intangible. Which are as follow?

- Charging the expenditure incurred on recruitment, training and development of human resources to current period's profit and loss account, profit during that period are understated or losses overstated.

- By not capitalizing expenses relating to human resource, even when they are substantial the assets are concealed and net worth is understated to that extent.

- Writing of goodwill when profits are rising, accountants create secret reserves.

- The historical cost approach to develop measures of human resource accounting uses an amortization rate, which provides the figure of amortization to be charge to the profit and loss account every year. But it is very difficult to develop norms in this regard. Physically and mentally, individuals grow and deteriorate at different rate. Some grow more capable as a result of their work experience, other do not. Given the difficulty of predicting such changes, it is even more difficult to develop a means of writing off and individual's value. So far, precise measures for amortization of human assets have not been developed.

- Though physical assets are fully recorded under the existing system, human assets are ignored in the internal as well as external reports. This lead to faulty evaluation and decisions.

- By not valuing human resources, on the principles of accounting depreciation or appreciation of human assets is ignored. There had been any attempt to systematically measure and report the depreciation or appreciation of human resource, the quality of management would certainly improve.

\section{Research Question or Hypotheses}

Traditional financial accounting considers only the fixed assets and current assets as assets and records this in the balance sheet of companies Annual reports, but the real asset, that is, the human assets are not taken into consideration. This accounting of human asset is done in human resource accounting. In developed countries, HRA is very well followed and is attached in their Annual reports.

Although, there is much research about HRA in developed countries, there is a gap in the literature on this area in developing and fast developing countries. Till today many of the Indian companies do not follow the HRA. Therefore it is necessary to raise certain questions on the following

- What is the nature and characteristics of HRA,

- To examine whether HRA is useful to the management or any other users who make use of HRA,

- How to analyze the perception of management and employees,

- How to determine the contribution of Human resource accounting on the financial statement of Indian companies - Public Companies and Private Companies and

- To know whether there is a relationship between the profitability of the company with human resource accounting disclosure.

These questions are called for an in-depth analysis on HRA so as to give the awareness about HRA and make benefits out of human resource accounting disclosures. Hence this study is carried out.

The following research hypotheses are framed and tested in the present study:

- H0: There is no significant difference between the socio-economic variables and the nature and characteristics of human resource accounting disclosures in Indian companies.

- H1: There is a significant difference between the socio-economic variables and the nature and characteristics of human resource accounting disclosures in Indian companies.

- HO: There is no significant difference between the socio-economic variables and the ability of users of human resource accounting to make wise decisions

- H1: There is a significant difference between the socio-economic variables and the ability of users of human resource accounting to make wise decisions.

- HO: There is no significant difference between the socio-economic variables and the perception of management and employees on human resource accounting.

- H1: There is a significant difference between the socio-economic variables and the perception of management and employees on human resource accounting. 
- HO: Accounting for human resource does not improve the financial position of Public Sector companies in India.

- H1: Accounting for human resource improves the financial position of Public Sector companies in India.

- H0: Accounting for human resource does not improve the financial position of Private Sector companies in India.

- H1: Accounting for human resource improves the financial position of Private Sector companies in India.

- H0: There is no significant difference between the profitability of the company and the extent of human resource accounting disclosures.

- H1: There is a significant difference between the profitability of the company and the extent of human resource accounting disclosures.

8. Review of Literature

\begin{tabular}{|c|c|c|c|c|c|}
\hline S.No & Title of article & Author & Year & Variable used & Conclusion \\
\hline 1 & $\begin{array}{l}\text { Investigation of the Influence of } \\
\text { Human Resources Accounting } \\
\text { Information on Managers' } \\
\text { Decision making in Social } \\
\text { Security Organization of } \\
\text { Khuzestan Province }\end{array}$ & IrajIsvan & 2014 & $\begin{array}{l}\text { There is } \\
\text { relationship between human } \\
\text { Resources } \\
\text { information and managers' } \\
\text { decisions in Social Security } \\
\text { Organization in Khuzestan } \\
\text { province. }\end{array}$ & $\begin{array}{l}\text { Correlation value is positive } \\
\text { and this shows that an } \\
\text { increase in human resources } \\
\text { accounting information can } \\
\text { result In managers' decisions } \\
\text { improvement }\end{array}$ \\
\hline 2 & $\begin{array}{l}\text { A comparison of Similarities } \\
\text { between Iranian and European } \\
\text { Organizations in Terms of Lack } \\
\text { of Attention to the Human } \\
\text { Resources }\end{array}$ & $\begin{array}{l}\text { Mohsen } \\
\text { ASGARI }\end{array}$ & 2013 & $\begin{array}{l}\text { The main goal of HR } \\
\text { accounting is to describe } \\
\text { potential capacity of the HR in } \\
\text { providing financial report of } \\
\text { the organization and Providing } \\
\text { economical values of the } \\
\text { human resource in order to } \\
\text { eliminate the shortcomings } \\
\text { traditional accounting. }\end{array}$ & $\begin{array}{l}\text { Based on ranking results, } \\
\text { lack knowledge of managers } \\
\text { about HRA is one of the } \\
\text { important and essential } \\
\text { reason lack } \\
\text { implementation and attention } \\
\text { to HRA }\end{array}$ \\
\hline 3 & $\begin{array}{l}\text { Problem with Human Resource } \\
\text { Accounting and A Possible } \\
\text { Solution }\end{array}$ & $\begin{array}{l}\text { Md. } \\
\text { MustafizurR } \\
\text { ahaman }\end{array}$ & 2013 & $\begin{array}{l}\text { The existing models proffered } \\
\text { under the HRA were } \\
\text { adequately reviewed and } \\
\text { objectively criticized so that } \\
\text { more comprehensive could be } \\
\text { developed. }\end{array}$ & $\begin{array}{l}\text { As an employee of an } \\
\text { organization will not merely } \\
\text { work for a single year, it } \\
\text { seems rational to account for } \\
\text { employee as an asset in the } \\
\text { balance sheet on the ground } \\
\text { that they will provide future } \\
\text { economic benefit to the } \\
\text { entity. }\end{array}$ \\
\hline 4 & $\begin{array}{l}\text { The Role of Human Resource } \\
\text { Accounting Information on the } \\
\text { Accounting Information System }\end{array}$ & $\begin{array}{l}\text { Dr. Adel M } \\
\text { Qatawneh }\end{array}$ & 2013 & $\begin{array}{l}\text { The statistical analysis showed } \\
\text { that human resource } \\
\text { accounting information had a } \\
\text { positive impact on the AIS and } \\
\text { that human resource } \\
\text { accounting information has a } \\
\text { significantly statistical } \\
\text { relationship with AIS itself }\end{array}$ & $\begin{array}{l}\text { Human resource accounting } \\
\text { information had a statistically } \\
\text { significant influence for } \\
\text { ability to reduce cost, } \\
\text { Improve operational } \\
\text { performance of through } \\
\text { accounting information } \\
\text { systems }\end{array}$ \\
\hline 5 & $\begin{array}{l}\text { A Review of Human Resource } \\
\text { Accounting and Organizational } \\
\text { Performance }\end{array}$ & $\begin{array}{l}\text { Jacob } \\
\text { Cherian }\end{array}$ & 2013 & $\begin{array}{l}\text { There is no legal regulation for } \\
\text { accounting human resources in } \\
\text { any of the organization's } \\
\text { annual report. The main aim of } \\
\text { this review is to study the } \\
\text { benefits of HR practices to the } \\
\text { firm. }\end{array}$ & $\begin{array}{l}\text { Human resources are } \\
\text { considered as building blocks } \\
\text { for any organization. it is } \\
\text { necessary to identify the } \\
\text { Contribution of the } \\
\text { employees to the firm. Then, } \\
\text { the evaluation measures of } \\
\text { "human resources" are } \\
\text { carried out. }\end{array}$ \\
\hline
\end{tabular}


6 The Role of Human Resources MeysamEiv 2013 Accounting at Research \& azi Development Centers

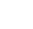

\section{Human Resources Accounting Augustine , \\ Disclosures in Nigeria Quoted O. Enofe} Firms

\begin{abstract}
Human resources accounting will provide required information for the manager in order to find and modify any allocation and maintenance and utilization, evaluation and compensation of human resources.
\end{abstract}

It was obvious that after all studies and researches companies may realize the real value of Human Resources Accounting. Up to now we found out a part of advantages of this resource including providing required information for different sections of an organization including financial department.

This study was carried out to Findings of the study indicate ascertain the relationship that financial companies such between firms' financial as banks and insurance performance and human companies in Nigeria are resources accounting disclosing human resources disclosures on one hand, and accounting information than the differences in human non-financial companies resources accounting disclosures reporting level between financial sector and non-financial sector companies quoted in the Nigerian Stock exchange.

\begin{tabular}{|c|c|c|c|c|}
\hline 8 & $\begin{array}{l}\text { Human Resource Accounting: } \\
\text { Recognition and Disclosure of } \\
\text { Accounting } \\
\text { Techniques }\end{array}$ & $\begin{array}{l}\text { Md. } \\
\text { Admiral } \\
\text { Islam }\end{array}$ & 2013 & $\begin{array}{l}\text { To understand the needs and } \\
\text { significance of HRA inThe } \\
\text { context of business } \\
\text { performance measurement. To } \\
\text { provide suggestions for } \\
\text { developing such Accounting } \\
\text { practices in our business } \\
\text { enternrises }\end{array}$ \\
\hline
\end{tabular}

\begin{tabular}{|c|c|c|c|c|c|}
\hline 9 & $\begin{array}{l}\text { Human Resources Accounting } \\
\text { Between Recognition and } \\
\text { Measurement: An Empirical } \\
\text { Study }\end{array}$ & $\begin{array}{l}\text { Khaled } \\
\text { Jamal Jaarat }\end{array}$ & 2013 & $\begin{array}{l}\text { researcher discussed and } \\
\text { investigated the possibility of } \\
\text { including the human resources } \\
\text { within the definition of asset, } \\
\text { and also, the possibility of } \\
\text { measuring the human } \\
\text { resources, and as a result } \\
\text { recognizing it }\end{array}$ & $\begin{array}{l}\text { The possibility of measuring } \\
\text { human resources, by using } \\
\text { one of the generally accepted } \\
\text { bases in Accounting that } \\
\text { included in conceptual } \\
\text { framework of financial } \\
\text { reporting issued by IASB. }\end{array}$ \\
\hline 10 & $\begin{array}{l}\text { Practice of human resource } \\
\text { accounting in banking sector of } \\
\text { Bangladesh }\end{array}$ & $\begin{array}{l}\text { Syed } \\
\text { Moudud- ul- } \\
\text { Huq }\end{array}$ & 2012 & $\begin{array}{l}\text { By the practicing of HRA an } \\
\text { organization can be benefited } \\
\text { in case of.a)Cost effectiveness } \\
\text { b)ensuring the best use of } \\
\text { human resources c)sound \& } \\
\text { effective basis for human asset } \\
\text { control d)The productivity of } \\
\text { human resources }\end{array}$ & $\begin{array}{l}\text { Bangladesh bank provides } \\
\text { guidelines towards to } \\
\text { practicing HRA, IASB issues } \\
\text { a standard for implementing } \\
\text { HRA, then the problems of } \\
\text { practicing HRA can alleviate } \\
\text { soon and commercial banks } \\
\text { in Bangladesh may continue } \\
\text { to boost the economy. }\end{array}$ \\
\hline
\end{tabular}

Over the last two decades the idea of accounting for human resources is gaining active consideration. So, HRA is not a new issue in economics. Economists consider human capital as a production factor, and they explore different ways of measuring its investment in business, agriculture, education, health, and other areas. Accountants have recognized the value of human assets for at least 50 years ago. Research into true HRA began in the 1960s by Rensis 
Likert (Bowers, 1973). Likert defends long-term planning by strong pressure on human resources' qualitative variables, resulting in greater benefits in the long run. American Accounting society on HRA defined HRA as the process of identifying, measuring data about human resources and communicating this information to interested parties. Stephen Knauf states that HRA is the measurement and quantification of human organizational inputs like recruiting, selecting, hiring, training, experience and communications. The experts in the field of HRA were Shultz (1960), William Pyle (1967), Flam Holtz (1973), Kenneth Sinclare (1978) and Roa (1983), etc who contributed appropriate methodology and correct methods for finding out the value of the employee to the organization. Accounting has special position and plays an important role in economic, trade and manufacturing development (Tomassini, et al. 1977). It is a man-made art and its principles, techniques and procedures have been evolved over a long period to aid business in reporting for the management and public. The four factors of production man, money, material and land, the last three of them are amenable to conventional accounting, but the first one, the human resource has not been subject to such accounting (Carme, Barcons et. al 1995).

\section{Scope of the Research}

The study is based on analysis of the information supplied in the questionnaire. As responses have been checked according to the perception of the person filling the questionnaire, the probability of certain amount of subjectivity in the response cannot be ruled out.

In preparing the questionnaire related to stock of human resource, labour turnover, absenteeism, age, qualification, grouping, earnings, own funds, total assets, HRD expenditure, net sales, profit information, capital employed etc. has been used.

- In this study the meaning of accounting is taken in the sense of information system. The main focus of the study is to examine and evaluate the existing accounting practices in respect of expenditure on human resource. More specifically, the study examines the accounting treatment regarding conducting interviews etc.

- The present study is a pilot project and an exploratory one conducted by an individual scholar. This study has not previewed all industries.

- It is conducted among the employees of selected companies from BSE SENSEX 200. The period of the study will be past 10 years.

- The study aims to reveal whether there is any impact of Human Resource Accounting on Indian Companies. Hence the present study is captioned as "Human Resource Accounting in Indian Companies".

- Overall quantum of audited industries was examined.

\section{Methodology of the Research}

\subsection{Study Population}

The population of this study consists of the total number of companies in the Bombay Stock Exchange Sensex (BSE 200). Out of which only 30 companies follow Human Resource Accounting. Hence these 30 companies, 16 Public Ltd. companies and 14 Private Ltd. companies have been selected as a sample unit for the study.

\subsection{Sample Design and Sampling techniques}

The present study used convenience sampling method and opinions have been collected from managers, accountants and employees in the respective companies. The companies which follow Human Resource Accounting have been selected as a sample unit for the study. Hence 30 companies have been selected as a sample unit for the study, 16 Public Ltd companies and 14 Private Ltd companies.

A pre-test has been conducted through pilot study so as to ensure the relevance and consistency of various items and statements in the questionnaire, inconsistent statements have been altogether dropped and others found appropriate. Based on the determination and allocation formula, 300 respondents have been selected as a sample size for the study.

\subsection{Collection of Data}

The present study has collected both primary and secondary data.

10.3.1 Primary Data

The primary data are collected from managers, accountants and employees of both Private and Public Ltd companies from the administration of questionnaire.

\section{Disclosure Relating To Human Resource Accounting}

11.1 Measurement of Human Resources

Human beings are the dynamic elements of every organization. The success of any organization, to a great extent, depends upon the quality and caliber of the people working in it. In other words, human resources are the most important asset of an organization. Thus, in spite of all technological developments, the importance of human resources has in no way diminished. With the advent of scientific management, which emphasis on quantitative 
methodology to make a most efficient use of all resources, also it includes the computation of the human resource capital.

OIL AND NATURAL GAS CORPORATION

Table-1. Total Number of Employees in ONGC during the period from 2008-09 to 2015-16

$\begin{array}{llllllllll}\text { Particulars } & & 2008 & 2009 & 2010 & 2011 & 2012 & 2013 & 2014 & 2015 \\ \text { Technical- Executive } & & 19349 & 19129 & 18780 & 18361 & 18684 & 18305 & 18379 & 19110 \\ \text { Technical - Non- Executive } & & 7567 & 7267 & 7135 & 6368 & 5194 & 5072 & 3997 & 3452 \\ \text { Total (A) } & 26916 & 26396 & 25915 & 24729 & 23878 & 23377 & 22376 & 22562 & \\ \text { Non- Technical Executive } & 4880 & 4655 & 4526 & 4451 & 4474 & 4365 & 4638 & 4834 & \\ \text { Non-Technical- Non-Executive } & 8484 & 8301 & 7592 & 7005 & 6370 & 6068 & 5982 & 5639 & \\ \text { Total (B) } & 13364 & 12956 & 12118 & 11456 & 10844 & 10433 & 10620 & 10473 \\ \text { Total Number of Employees } & & 40280 & 39352 & 38033 & 36185 & 34722 & 33810 & 32996 & 33035 \\ \text { (Index) } & 100 & 97.7 & 94.42 & 89.83 & 86.2 & 83.94 & 81.92 & 82.01 & \end{array}$

(Index)

Source: Annual Reports of ONGC during the period from 2008-09 to 2015-16

HINDUSTAN PETROLIUM CORPORATION LIMITED

The numbers of employees under HPCL are classified among Management and Non- Management

Table -2. Total Number of Employees in HPCL during the period from 2008-09 to 2014-15

\begin{tabular}{|c|c|c|c|c|c|c|c|c|c|}
\hline Particulars & & 2008 & 2009 & 2010 & 2011 & 2012 & 2013 & 2014 & 2015 \\
\hline Management & & 3571 & 3583 & 3594 & 3562 & 3866 & 4074 & 4094 & 4551 \\
\hline Non-Management & & 7786 & 7630 & 7494 & 6999 & 6912 & 6817 & 6855 & 6695 \\
\hline Total Number of Employees & & 11357 & 11213 & 11088 & 10561 & 10778 & 10891 & 10949 & 11246 \\
\hline (Index) & 100 & 98.73 & 97.63 & 92.99 & 94.9 & 95.9 & 96.41 & 99.02 & \\
\hline
\end{tabular}

Source: Annual Reports of HPCL during the period from 2008-09 to 2015-16

CEMENT CORPORATION OF INDIA LIMITED (CCI)

The number of employees under CCI is classified among executives, supervisors, skilled workers, semi - skilled workers, clerical and other supporting staff and unskilled workers.

Table -3. Total Number of Employees in CCI during the period from 2008-09 to 2015-16

\begin{tabular}{|c|c|c|c|c|c|c|c|c|c|}
\hline Particulars & & 2008 & 2009 & 2010 & 2011 & 2012 & 2013 & 2014 & 2015 \\
\hline Executives & & 303 & 237 & 188 & 182 & 173 & 165 & 150 & 134 \\
\hline Supervisors & & 445 & 335 & 206 & 204 & 199 & 187 & 176 & 178 \\
\hline Skilled Workers & 1089 & 762 & 552 & 577 & 577 & 580 & 534 & 388 & \\
\hline Semi-Skilled Workers & 404 & 293 & 202 & 238 & 237 & 223 & 233 & 184 & \\
\hline Clerical \& Other Supporting Staff & 426 & 289 & 250 & 212 & 212 & 201 & 209 & 150 & \\
\hline Unskilled Workers & & 346 & 218 & 209 & 173 & 172 & 167 & 158 & 125 \\
\hline Total & & 3013 & 2134 & 1607 & 1586 & 1570 & 1523 & 1460 & 1159 \\
\hline (Index) & 100 & 70.83 & 53.33 & 52.64 & 52.11 & 50.55 & 48.46 & 38.47 & \\
\hline
\end{tabular}

Source: Annual Reports of CCI during the period from 2008-09 to 2015-16

\section{OIL INDIA LIMITED (OIL)}

The number of employees under OIL is classified among Technical - Executive, Technical - Workmen and Administrative - Executive, Administrative - Workmen.

Table -4. Total Number of Employees in OIL during the period from 2008-09 to 2014-15

Particulars

Technical- Executive

Technical - Workmen

Total (A)

Administrative -Executive

Administrative - Workmen

Total (B)

Total Number of Employees

(Index)

$\begin{array}{lllllllll} & 2008 & 2009 & 2010 & 2011 & 2012 & 2013 & 2014 & 2015 \\ & \text { NR } & 994 & 1264 & 1256 & 1122 & & & \\ \text { NR } & 6952 & 5833 & 5426 & 5131 & 7304 & 7249 & 7127 & \\ & \text { NR } & 7946 & 7097 & 6682 & 6253 & & & \\ & \text { NR } & 599 & 422 & 456 & 607 & & & \\ & \text { NR } & 1020 & 1254 & 1549 & 1798 & 1172 & 1182 & 1260 \\ & \text { NR } & 1619 & 1696 & 2005 & 2405 & & & \\ 9725 & 9565 & 8793 & 8687 & 8658 & 8476 & 8431 & 8387 & \\ 100 & 98.35 & 90.42 & 89.33 & 89.03 & 87.16 & 86.69 & 86.24 & \end{array}$

Source: Annual Reports of OIL during the period from 2008-09 to 2015-16 
DISCLOSURE OF SELECTED VARIABLE FOR HR RELATED INFORMATION BY SELECTED COMPANIES. $\mathrm{D}=$ Disclosed ND= Not Disclosed

Table- 5. Disclosure of Various Variables

Disclosure of Variables

\begin{tabular}{|c|c|c|c|c|c|c|c|c|c|}
\hline $\begin{array}{l}\text { Company } \\
\text { Value Added }\end{array}$ & & $\begin{array}{l}\text { ONGC } \\
\text { D }\end{array}$ & HPCL & $\begin{array}{l}\text { CCI } \\
\text { D }\end{array}$ & & $\begin{array}{l}\text { OIL } \\
\text { D }\end{array}$ & & $\begin{array}{l}\text { Total } \\
\text { ND }\end{array}$ & \\
\hline $\begin{array}{l}\text { Value Added } \\
\text { No of Employee }\end{array}$ & $\mathrm{D}$ & & $\mathrm{D}$ & & $\mathrm{D}$ & & $\mathrm{D}$ & & 4 \\
\hline EVA & & $\mathrm{D}$ & & ND & & $\mathrm{D}$ & & ND & \\
\hline Value of HR & & ND & & ND & & $\mathrm{D}$ & & ND & \\
\hline Value of HR per Employe & & ND & & ND & & $\mathrm{D}$ & & ND & \\
\hline Value Added per Employe & & $\mathrm{D}$ & & ND & & ND & & ND & \\
\hline Valuation Model Used & $\mathrm{D}$ & & $\mathrm{D}$ & & $\mathrm{D}$ & & ND & & 3 \\
\hline Discount rate applied & & $\mathrm{D}$ & & $\mathrm{D}$ & & D & & ND & \\
\hline Age wise Distribution & ND & & ND & & $\mathrm{D}$ & & ND & & 1 \\
\hline Group Wise Distribution & $\mathrm{D}$ & & $\mathrm{D}$ & & $\mathrm{D}$ & & ND & & 3 \\
\hline Gender Wise Distribution & ND & & ND & & $\mathrm{D}$ & & ND & & 1 \\
\hline Turnover per Employee & $\mathrm{D}$ & & ND & & ND & & ND & & 1 \\
\hline Employee cost & ND & & ND & & $\mathrm{D}$ & & $\mathrm{D}$ & & 2 \\
\hline Total Identified Variables & 8 & & 5 & & 11 & & 2 & & 26 \\
\hline
\end{tabular}

Table-5 shows Human Resource Accounting disclosure practices by ONGC, HPCL, CCI and OIL. The table helps to understand which company provides more information regarding its HR. It can be seen that CCI provides 11 type of information (i.e. 84.6\%) out of 13 listed information. ONGC disclose the 8 type of information (i.e. $61.53 \%$ ), than comes HPCL, it provide the 5 type of information (i.e. 38.46\%) and OIL provide only 2 type of information $(15.38 \%)$.

\subsection{Measurement of Human Resources}

Human beings are the dynamic elements of every organization. The success of any organization, to a great extent, depends upon the quality and caliber of the people working in it. In other words, human resources are the most important asset of an organization. Thus, in spite of all technological developments, the importance of human resources has in no way diminished. With the advent of scientific management, which emphasis on quantitative methodology to make a most efficient use of all resources, also it includes the computation of the human resource capital.

Table indicates the value of employees' vis-à-vis total no. of employees as per Lev and Schwartz model. The total value of employees of sampled organizations is about 15 crores. According to this table, ONGC indicates the highest value of employees i.e. $87.09 \%$ and it also have highest percentage among total number of employees 53.9\% $(17,000 \mathrm{employees})$. The second company which have highest value is HPCL i.e. $4.22 \%$ value. But the table shows that there are some companies in sample that have higher number of employees but value of their human resources is not higher likes OIL that has employed $11.46 \%$ (3,620 employees) but their human worth is only $2.3 \%$ that is too much less than number of employees. Thus, in spite of large number of employees, value of human capital is not high. The lowest value of human capital is represented by CCI which employed $0.063 \%$ employees and their human worth is only $0.004 \%$.

Table-6.Total Value of HR as per Lev and Schwartz Model

\begin{tabular}{llll}
\hline S.No. & Name of Company & No. of Employees & Value of Human resource in Cores \\
\hline 1 & $\begin{array}{l}\text { Oil \& Natural Gas Corporation Ltd. } \\
\text { (ONGC) }\end{array}$ & 33035 & $3,620(11.46)$ \\
\hline 2 & $\begin{array}{l}\text { Hindustan Petroleum Corporation Ltd. } \\
\text { (HPCL) }\end{array}$ & 11246 & $1,568(4.96)$ \\
\hline 3 & Cement Corporation of India Ltd. (CCI ) & 1159 & $53(0.167)$ \\
\hline 4 & Oil India Ltd. (OIL) & 8387 & $790(0.60)$ \\
\hline
\end{tabular}

11.3 Per Capital Value of Human Resources

Source: Data Compiled from questionnaire

High performing organizations in order to keep performing on a continuous basis must treat their human capital as the most important and valuable asset. They should treat them as adults, as partners and with dignity and respect. As we all know that 'People who feel good about themselves produce good results' and People who produce good results feel good about themselves'. Such a healthy and virtuous cycle goes on and on, satisfying the individual 
goals and organizational goals too at the same time, in that the individual drives the job satisfaction, which in turn induces him to reach out for excellence, culminating in the all-round development of the performing organizations. In recent years, India has evolved from an inward looking economy to one with a global orientation. Today, the company exports large number of products to various destinations than ever before. Sound human resources not only facilitate to improve a firm's long run responsiveness and flexibility also thereby competitiveness. Table indicates the value per employee and number of employees working in organization. ONGC have the highest number of employees i.e. 17,000 and value per employee is also very high i.e. 80 lakh. After ONGC, HPCL have the highest value 46.4 lakh of each employee that is very high in comparison to the number of employees' i.e only 200 but the value shows that human resources are very important for these organizations.

Table 7: Value of HR per employee as per Lev and Schwartz Model

\begin{tabular}{llll}
\hline S.No. & Name of Company & No. of Employees & Value of Human resource in Cores \\
\hline 1 & $\begin{array}{l}\text { Oil \& Natural Gas Corporation Ltd. } \\
(\text { ONGC) }\end{array}$ & $3,620(11.46)$ & 10.3 \\
\hline 2 & $\begin{array}{l}\text { Hindustan Petroleum Corporation Ltd. } \\
\text { (HPCL) }\end{array}$ & $1,568(4.96)$ & 42.3 \\
\hline 3 & Cement Corporation of India Ltd. (CCI ) & $53(0.167)$ & 12.6 \\
\hline 4 & Oil India Ltd. (OIL) & $790(0.60)$ & 7.7 \\
\hline
\end{tabular}

\subsection{Hierarchical Per Capita Human Resources}

Source: Data Compiled from questionnaire

Human beings are the dynamic elements of the organization. The success of an enterprise will depend upon the caliber and motivation of persons working in it. The success of an organization depends upon the effective and meaningful utilization of men, materials and money. Infract, business is a system which consists of elements and inter-connections between elements. One cannot simply say that the value generated by a business consists of the sum of the value generated by individual elements. Value arises because each of the elements performs various functions and because these functions interact.

Table 8.Value of HR per employee as per level of Lev and Schwartz Model

\begin{tabular}{|c|c|c|c|c|c|}
\hline S.No. & Name of Company & $\begin{array}{l}\text { Value } \\
\text { Employee } \\
\text { Higher Level }\end{array}$ & $\begin{array}{ll}\text { of } & \text { Value } \\
\text { at } & \text { Employee } \\
& \text { Middle Level } \\
\end{array}$ & $\begin{array}{ll}\text { of } & \text { Value } \\
\text { at } & \text { Employee } \\
& \text { Lover Level } \\
\end{array}$ & $\begin{array}{l}\text { Value per } \\
\text { employee }\end{array}$ \\
\hline 1 & $\begin{array}{l}\text { Oil \& Natural Gas Corporation Ltd. } \\
\text { (ONGC) }\end{array}$ & 143.90 & 79.4 & 2.92 & 75.44 \\
\hline 2 & $\begin{array}{l}\text { Hindustan Petroleum Corporation } \\
\text { Ltd. (HPCL) }\end{array}$ & 37.5 & 31.7 & 5.6 & 24.9 \\
\hline 3 & $\begin{array}{l}\text { Cement Corporation of India Ltd. } \\
\text { (CCI ) }\end{array}$ & 25 & 9.74 & 7.8 & 42.5 \\
\hline 4 & Oil India Ltd. (OIL) & 44.9 & 17.5 & 3.3 & 65.7 \\
\hline
\end{tabular}

Source: Data Compiled from questionnaire

The enterprises follow someone similar practice evolved out of the synthesis of the three approaches based on economic value as advocated by Lev and Schwartz, Flamholtz and Jaggi and Lew may appear to be an improved version. The present value approach to HRA is still in the experimental stage. But, it is already required in valuing some specific under general accepted human accounting standards. HR value may reflect the present value of future liability of an organization towards employer wage payment. It does not reflect the value of HR as an asset, nor does it facilitate to manage the same as an asset as against expense in the traditional accounting practice. The cost of the wages may have to be judged in relation to the services they render to access their value and improve organizational productivity. Besides the wages as a servicing cost of employees, the cost of manpower acquisition may be no less relevant. Formulation of generally accepted human accounting standard is essential at this juncture. It may not represent the value of the HR as proposed in the historical cost based HRA, but the same cost elements may have to be recognized while judging the extent of the services, the employees render to the organization to reflect their value. The value assigned by Indian companies to their human resources just denotes the present value of the costs with respect to remaining service life of an employee in the organization rather than their contribution that it will receive from $\mathrm{HR}$.

\section{Obstacles in HRA}

Although, the theory of HRA appears to be useful, the redistill lack of adequate standards for the valuation of HR. The mere process of putting number to things can easily be taken outside the context of their proper use. It is likely that managers will treat human quantitative data not different from quantitative data regarding the physical plant and 
machinery. The managers may use HRA as a means of manipulating the employee. She/he may decrease the value of an employee as a form of punishment or control. This may be done by altering the variables like the probability of an employee being promoted to the next state, future increments etc., determining the value of HR. The employee's bargaining power might be increased if his/her value was known. However, power might be increased if his/her value was known.

\section{Conclusion}

HRA being an emerging area in accounting has greater potential for further research. The model devised so far, for the valuation of HRA, has been developed in USA keeping into consideration the environments prevailing there. There is a great need to review their applicability in India, a country which is substantially facing different environments. The special studies needed periodically to calculate cost of turnover, cost-benefit analysis of training and the cost of labor etc., must be a joint effort since many value judgments and assumptions must be made and understood by the prepares of data as well as the user. HRA has a promise; it has not yet met the test of usage. Much more research is necessary before HRA can possibly be useful to operating managers.

\section{References}

Iraj Isvan (2014).Investigation of the Influence of Human Resources Accounting Information on Managers' Decision-Making in Social Security Organization of Khuzestan Province.Journal of Applied Environmental and Biological Sciences.

Mohsen Asgari.(2013).A comparison of Similarities between Iranian and European Organizations in Terms of Lack of Attention to the Human Resources Accounting .International Journal of Academic Research in Accounting, Finance and Management Sciences,3(1),265-270.

Mustafizur Rahaman.(2013). Problem with Human Resource Accounting and A Possible Solution.Research Journal of Finance and Accounting,4(18).

Adel M Qatawneh(2013). The Role of Human Resource Accounting Information on the Accounting Information System .European Journal of Business and Management, Jacob Cherian, A Review of Human Resource Accounting and Organizational Performance International.Journal of Economics and Finance,5(8).

Meysam Eivazi, Morteza Ranjkesh, The Role of Human Resources Accounting at Research \& Development Centers National park-Forschung In Der Schweiz. Switzerland Research Park Journal.

A.O. Enofe, Dr. C. Mgbame, Sunday Otuya.(2013). Human Resources Accounting Disclosures in Nigeria Quoted Firms .Research Journal of Finance and Accounting,4(13).

Amirul Islam, Md. Kamruzzaman \& Md. Redwanuzzaman Human Resource Accounting: Recognition and Disclosure of Accounting Methods \& Techniques By Md. Global Journal of Management and Business .Research Accounting and Auditing,13(3).

Khaled Jamal Jaarat.(2013).Human Resources Accounting Between Recognition and Measurement: An Empirical Study .Journal of Business Studies Quarterly ,5(2).

Dasari, P., Chand D. B. \& Rajasekhar D. 2013, 'A Study On Human Resource Accounting Methods And Practices In India', International Journal Of Social Science \& Interdisciplinary Research,2(4).

Maria L. B., Kel A. E. (2013).'Human resource accounting and international developments: implications for measurement of human capital', Journal of International Business and Cultural Studies Human Resource Accounting.

Zafor Mamoon .(2013).Human Resource Accounting For Decision Making. International Journal of Innovative Research \& Development. (2).

Syed Moudud- UL- HUQ.(2012). Practice of human resource accounting in banking sector of Bangladesh .International journal of accounting and financial management research.

Asha Sharma Impact Of Human Resources Accounting On Organizational Performance.(2012).IOSR Journal of Business and Management .(5)1

Fariborz A. \& Raiashekar D.H. (2011).Decision-Making Based on Human Resource Accounting Information and Its Evaluation Method, Asian Journal of Finance \& Accounting, 3(1),14.

Lawler, E. E. (2009). Make human capital a source of competitive advantage. Organizational Dynamics, 38(1), 17. http://dx.doi.org/10.1016/j.orgdyn.2008.10.007

Baker \& McKenzie (2010).Australian Master Human Resources guide.CCH Australia Limited.Macquarie University. Graduate School of Management : 51

Mukesh Chauhan \& Shivani Gupta.(2009).Human Resource Accounting - concepts \& practices in India”. The management accountant. (44)

Bras, F. A. \& Rodrigues, L.L. (2007). Accounting for firms' training programs: An exploratory study, 11 (3), 229. 
Andrikopoulos, A. (2005). Using intellectual capital statements to determine valuedrivers and priorities for organizational change: a portfolio selection approach. Knowledge Management Research \& Practice, 3 (3), 166.

\section{Copyrights}

Copyright for this article is retained by the author(s), with first publication rights granted to the journal. This is an open-access article distributed under the terms and conditions of the Creative Commons Attribution license (http://creativecommons.org/licenses/by/4.0/). 